\title{
STAT3 expression is correlated with pathological stage in luminal subtypes of breast carcinoma
}

\author{
Eroglu $\mathrm{M}^{1}$, Kokenek-Unal $\mathrm{TD}^{2}$, Akin-Bali $\mathrm{DF}^{3}$, Kirimlioglu $\mathrm{SH}^{4}$ \\ Nigde Omer Halisdemir University, Faculty of Medicine, Department of Pathology, Nigde, Turkey. \\ dilarafatmaakin@gmail.com
}

\begin{abstract}
AIM: STATs and HIFs in human solid tumors play an important role in mechanisms of tumor growth. The aim of this study was to determine the prognostic role of STATs and HIFs in breast cancers.

METHODS: Twenty-four breast carcinoma cases who underwent mastectomy and axillary dissection were included into the study. The presence of STATs and HIFs in 24 breast cancer cases was evaluated immunohistochemically. We evaluated the differences in tumor grade, diameter, limits, intratumor desmoplasia, inflammatory infiltration, necrosis, axillary lymph node involvement, estrogen, progesterone and CerbB2 staining.

RESULTS: In this study, the presence of STATs and HIFs expressions in breast tumors is shown. In our study, no statistically significant correlation was found between tumor grade, diameter, limits, intratumor desmoplasia, inflammatory infiltration, necrosis, axillary lymph node involvement, CerbB2 staining status and STATs and HIFs expressions. However, STAT5a and estrogen staining and HIF2 $\alpha$ and progesterone staining were found statistically significant. In addition, STAT3 expression was found to have significantly higher correlation with luminal breast cancer.

CONCLUSIONS: The findings suggest that STATs and HIFs may play a role in the development of invasive ductal carcinomas; concerning their future use as treatment options due to their association with hormone receptors, new studies are required (Tab. 6, Fig. 7, Ref. 65). Text in PDF www.elis.sk.

KEYWORDS: Breast carcinoma, prognostic characteristics, HIF1 $\alpha$, HIF2 $\alpha$, STAT1, STAT2, STAT3, STAT5a, STAT5b.
\end{abstract}

\section{Introduction}

Breast carcinomas are the most common malignant tumors in women, and more than 1,000,000 women worldwide each year are diagnosed with breast carcinoma. It is also the most common cause of death from carcinomas in women (1). Literature mentions the importance of numerous genetic and histologic parameters, especially patient age and early diagnosis in breast cancer prognosis. The most important prognostic factors are the histologic grade and stage of the tumor. However, there is also a need for new parameters for identifying new treatment strategies, preventing cancer development in people at high risk of cancer, as well as for predicting the prognosis. Cancer cells can survive and proliferate in unusual microenvironment. Intratumoral hypoxia plays

${ }^{1}$ Nigde Omer Halisdemir University, Faculty of Medicine, Department of Pathology, Nigde, Turkey, ${ }^{2}$ Health Sciences University, Kayseri Research and Training Center, Department of Pathology, Kayseri, Turkey, ${ }^{3}$ Nigde Omer Halisdemir University, Faculty of Medicine, Medical Biology, Nigde, Turkey, and ${ }^{4}$ Acibadem Mehmet Ali Aydinlar University, Department of Pathology, Istanbul, Turkey

Address for correspondence: D.F. Akin-Bali, Nigde Omer Halisdemir University, Faculty of Medicine, Medical Biology, Nigde, Turkey. Phone: +905363026816 .

Acknowledgement: This study was supported by Inonu University Scientific Research Projects Unit with the project number of 2008/30. an important role especially in the development of fast growing solid tumors. The adaptation to hypoxic environment for the survival and development of tumor cells is mainly determined by the HIF (hypoxia inducing factor)-dependent transcription program (2). It is stated that high levels of HIFs in human tumors play an important role in tumor growth by regulating the anaerobic energy metabolism, angiogenesis, continuity of cells and target genes that play a role in drug resistance (2-7). HIF $1 \alpha$ and HIF $2 \alpha$ are important proteins that induce tumor cell response to hypoxia and are responsible for carcinogenesis and clinical behavior of tumors (7). Signal transducer and activator of transcription (STAT) proteins are transcription factors that regulate the growth and differentiation of cells, and they are activated in response to cytokines and growth factors, particularly to cytokines in the JAK / STAT signaling pathway (8-12). As a result of the studies, STAT types have been found to have special functions (13). It has been reported that a large number of tumors are associated with increased activation levels of STATs, in particular with STAT3 and STAT5 (14-17). In studies conducted on breast carcinomas, STAT activation has been shown to be associated with invasive breast carcinoma, not with benign and in situ carcinoma (18). The aim of this study was to offer an immunohistochemical evaluation of the expressions of HIF $1 \alpha$ and HIF $2 \alpha$ proteins associated with vascularization and hypoxia in invasive ductal carcinomas as well as that of expressions of the STAT family (STAT1, STAT2, STAT3, STAT5a, STAT5b) 
$51-61$

Tab. 1. STAT 1 immmunohistochemical expression and histopathological parameters.

\begin{tabular}{|c|c|c|c|c|c|}
\hline \multirow{2}{*}{ Parameters } & & \multicolumn{4}{|c|}{ Immunohistochemical expression of STAT 1 antibody. } \\
\hline & & Negative & Positive & Correlation & $\mathrm{p}$ \\
\hline Age & $\begin{array}{l}<40 \\
>40\end{array}$ & $\begin{array}{l}0 \\
4\end{array}$ & $\begin{array}{l}4 \\
16\end{array}$ & 0.123 & 0.327 \\
\hline Histological grade & $\begin{array}{l}\text { Grade I } \\
\text { Grade II } \\
\text { Grade III } \\
\end{array}$ & $\begin{array}{l}1 / 7(14.3 \%) \\
0 / 8 \\
3 / 9(33.3 \%)\end{array}$ & $\begin{array}{l}6 / 7(85.7 \%) \\
8 / 8(100 \%) \\
6 / 9(66.7 \%) \\
\end{array}$ & 0.009 & 0.273 \\
\hline Tumor diameter & $\begin{array}{l}<2 \\
2-5 \\
>5 \\
\end{array}$ & $\begin{array}{l}2 / 9(22.2 \%) \\
1 / 11(9.1 \%) \\
1 / 4(25 \%) \\
\end{array}$ & $\begin{array}{l}7 / 9(77.8 \%) \\
10 / 11(90.9 \%) \\
3 / 4(75 \%)\end{array}$ & -0.030 & 0.627 \\
\hline necrosis & $\begin{array}{l}\text { Present } \\
\text { absent }\end{array}$ & $\begin{array}{l}2 / 7(28.6 \%) \\
2 / 17(11.8 \%) \\
\end{array}$ & $\begin{array}{l}5 / 7(71.4 \%) \\
15 / 17(88.2 \%) \\
\end{array}$ & 0.192 & 0.552 \\
\hline Inflammation & $\begin{array}{l}\text { Present } \\
\text { absent }\end{array}$ & $\begin{array}{l}\text { 4/21 (19\%) } \\
0 / 3\end{array}$ & $\begin{array}{l}17 / 21(81 \%) \\
3 / 3(100 \%)\end{array}$ & -0.167 & 1.000 \\
\hline Tumor growth pattern at borders & $\begin{array}{l}\text { Infiltratif } \\
\text { expansile }\end{array}$ & $\begin{array}{l}3 / 21(14.3 \%) \\
1 / 3(39.3 \%)\end{array}$ & $\begin{array}{l}18 / 21(85.7 \%) \\
2 / 3(66.7 \%)\end{array}$ & -0.056 & 0.437 \\
\hline cerbB2 status & $\begin{array}{l}\text { Negative } \\
\text { uncertain }\end{array}$ & $\begin{array}{l}4 / 17(33.5 \%) \\
0 / 3 \\
0 / 4\end{array}$ & $\begin{array}{l}13 / 17(76.5 \%) \\
3 / 3(100 \%) \\
4 / 4(100 \%)\end{array}$ & 0.103 & 0.744 \\
\hline ER status & $\begin{array}{l}\text { Negative } \\
\text { positive }\end{array}$ & $\begin{array}{l}1 / 7(14.3 \%) \\
6 / 7(85.7 \%) \\
\end{array}$ & $\begin{array}{l}3 / 17(17.6 \%) \\
14 / 17(82.4 \%) \\
\end{array}$ & -0.038 & 1.000 \\
\hline PR status & $\begin{array}{l}\text { Negative } \\
\text { positive }\end{array}$ & $\begin{array}{l}0 / 3 \\
3 / 3(100 \%)\end{array}$ & $\begin{array}{l}4 / 21(19 \%) \\
17 / 21(81 \%) \\
\end{array}$ & -0.167 & 1.000 \\
\hline Hormone receptor status & $\begin{array}{l}\text { Positive } \\
\text { Negative }\end{array}$ & $\begin{array}{l}4 / 21(19 \%) \\
0 / 3\end{array}$ & $\begin{array}{l}17 / 21(81 \%) \\
3 / 3(100 \%)\end{array}$ & -0.167 & 1.000 \\
\hline LN metastasis & $\begin{array}{l}\text { Present } \\
\text { absent }\end{array}$ & $\begin{array}{l}2 / 12(16.7 \%) \\
2 / 12(16.7 \%)\end{array}$ & $\begin{array}{l}10 / 12(83.3 \%) \\
10 / 12(83.3 \%)\end{array}$ & 0.000 & 1.000 \\
\hline Pathological stage & $\begin{array}{l}\mathrm{Ib} \\
\mathrm{IIa} \\
\mathrm{IIb}\end{array}$ & $\begin{array}{l}1 / 11(9.1 \%) \\
3 / 10(30 \%) \\
0 / 3\end{array}$ & $\begin{array}{l}10 / 11(90.9 \%) \\
7 / 10(70 \%) \\
3 / 3(100 \%) \\
\end{array}$ & -0.157 & 0.317 \\
\hline
\end{tabular}
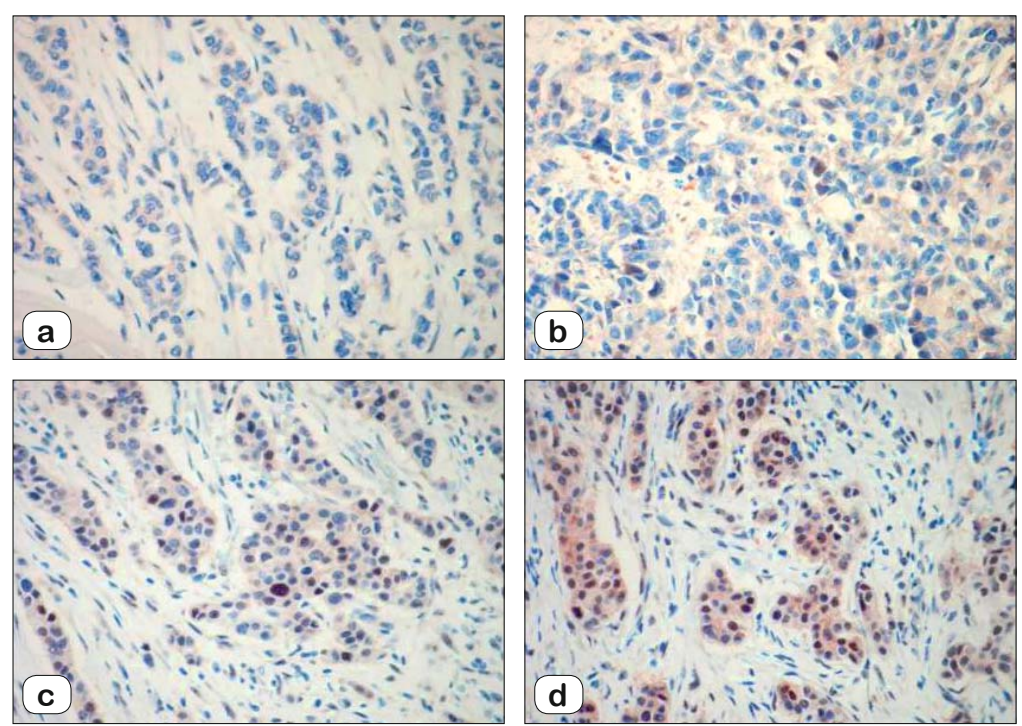

Fig. 1. No staining was detected with STAT1 in 4/24 of tumor cases (G0) (a), G1 (b) expression in 4 cases, G2 (c) in 11 cases, G3 (d) STAT1 expression in 5 cases were detected.

in relation to cell growth and differentiation. In this study, we aimed at a comparative evaluation of the potential relationship of STATs and HIFs with numerous significant parameters involved in the prognosis of breast cancer such as the presence of lymph node metastasis, inflammatory cell infiltration, presence of des- moplastic stromal reaction, presence of necrosis, histologic grade, tumor size, hormone receptor status, CerbB2 expression and pathological stage.

\section{Materials and methods}

In this study, upon the approval of the local ethics committee (Decision no: 2008/15), 24 cases who underwent mastectomy and axillary dissection at the Department of General Surgery at Inonu University Faculty of Medicine, and were diagnosed with invasive ductal carcinoma at the Department of Medical Pathology between 2002 and 2008, were examined through retrospective archival research. With a scan of glass slides of all the cases, histopathological parameters such as tumor size, tumor nuclear grade, presence of desmoplasia, presence and degree of concomitant inflammation, presence of necrosis, tumor growth pattern, ER, PR and cerbB2 positivity, presence of lymph node metastasis and pathological stage were evaluated. For the study, blocks containing tumoral and nontumoral areas were identified. Sections transferred from the selected blocks to polylysine-coated glass slides were stained immunohistochemically with STAT1, STAT2, STAT3, STAT5a, STAT5b, HIF $1 \alpha$, HIF $2 \alpha$ antibodies in accordance with the protocols of the 
Tab. 2. STAT 2 immmunohistochemical expression and histopathological parameters.

\begin{tabular}{|c|c|c|c|c|c|}
\hline \multirow{2}{*}{ Parameters } & & \multicolumn{4}{|c|}{ Immunohistochemical expression of STAT 2 antibody. } \\
\hline & & Negative & Positive & Correlation & $\mathrm{p}$ \\
\hline \multirow[t]{2}{*}{ Age } & $<40$ & 0 & 4 & \multirow{2}{*}{0.038} & \multirow{2}{*}{0.509} \\
\hline & $>40$ & 2 & 18 & & \\
\hline \multirow[t]{3}{*}{ Histological grade } & Grade I & $0 / 8$ & $7(100 \%)$ & \multirow{3}{*}{0.033} & \multirow{3}{*}{0.178} \\
\hline & Grade II & $2 / 8(25 \%)$ & $6(75 \%)$ & & \\
\hline & Grade III & $0 / 9$ & $9(100 \%)$ & & \\
\hline \multirow[t]{3}{*}{ Tumor diameter } & $<2$ & $0 / 9$ & 9/9 (100\%) & \multirow{3}{*}{0.048} & \multirow{3}{*}{0.641} \\
\hline & $2-5$ & 2/11 (18.6\%) & 9/11 (81.4 \%) & & \\
\hline & $>5$ & $0 / 4$ & $4 / 4(100 \%)$ & & \\
\hline \multirow[t]{2}{*}{ necrosis } & Present & $0 / 7$ & $7(100 \%)$ & \multirow{2}{*}{-0.149} & \multirow{2}{*}{1.000} \\
\hline & absent & $2 / 17(11.8 \%)$ & $15(88.2 \%)$ & & \\
\hline \multirow[t]{2}{*}{ Inflammation } & Present & $2 / 21(9.5 \%)$ & $19(90.5 \%)$ & \multirow{2}{*}{-0.111} & \multirow{2}{*}{1.000} \\
\hline & absent & $0 / 3$ & $3(100 \%)$ & & \\
\hline \multirow[t]{2}{*}{ Tumor growth pattern at borders } & Infiltratif & $2 / 21(9.5 \%)$ & $19(90.5 \%)$ & \multirow{2}{*}{0.026} & \multirow{2}{*}{1.000} \\
\hline & expansile & $0 / 3$ & $3(100 \%)$ & & \\
\hline \multirow[t]{3}{*}{ cerbB2 status } & Negative & 2/17 (11.8\%) & $15 / 17(88.2 \%)$ & \multirow{3}{*}{0.048} & \multirow{3}{*}{1.000} \\
\hline & uncertain & $0 / 4$ & $4 / 4(100 \%)$ & & \\
\hline & positive & $0 / 3$ & $3 / 3(100 \%)$ & & \\
\hline \multirow[t]{2}{*}{ ER status } & Negative & $1 / 7(14.3 \%)$ & $1 / 17(5.9 \%)$ & \multirow{2}{*}{0.106} & \multirow{2}{*}{0.507} \\
\hline & positive & $6 / 7(85.7 \%)$ & $16 / 17(94.1 \%)$ & & \\
\hline \multirow[t]{2}{*}{ PR status } & Negative & $1 / 3(33.3 \%)$ & $1 / 21(4.8 \%)$ & \multirow{2}{*}{0.333} & \multirow{2}{*}{0.239} \\
\hline & positive & $2 / 3(66.7 \%)$ & $20 / 21(95.2 \%)$ & & \\
\hline \multirow[t]{2}{*}{ Hormon receptor status } & Positive & $1 / 21(4.8 \%)$ & $20 / 21(95.2 \%)$ & \multirow{2}{*}{0.333} & \\
\hline & Negative & $1 / 3(33.3 \%)$ & $2 / 3(66.7 \%)$ & & 0.239 \\
\hline LN metastasis & Present & $1 / 12(8.3 \%)$ & $11 / 12(91.7 \%)$ & & \\
\hline & absent & $1 / 12(8.3 \%)$ & $11 / 12(91.7 \%)$ & 0.000 & 1.000 \\
\hline Pathological stage & $\mathrm{Ib}$ & 1/11 (9.1\%) & 10/11 (90.9\%) & & \\
\hline & IIa & $1 / 10(10 \%)$ & $9 / 10(90 \%)$ & -0.006 & 1.000 \\
\hline & IIb & $0 / 3$ & 3/3 (100\%) & & \\
\hline
\end{tabular}

producer. The stained slides were examined, and the presence of tumor cells exhibiting cytoplasmic staining for HIF $2 \alpha$, and nuclear staining for others was considered as positive staining. Cytoplasmic staining patterns were also noted. The staining of epithelial and mesenchymal cells and lymphocytes in tumor cells and non-tumor tissues was also evaluated separately. The evaluation was first done by two pathologists independent of each other, and later was repeated by them together. The staining was graded in consideration of the percentage of cells stained positively in 10 different areas under the light microscope.

Grades $0,1,2$ and 3, refer to staining in less than $10 \%, 10-50 \%, 51-75 \%$ and over $75 \%$ of cells, respectively. In the final analysis, Grade 0 was considered as negative, while Grades 1, 2 and 3 were assessed as positive results. In addition to staining results and demographic data, the pathological stages of patients were compared with histopathological parameters such as the
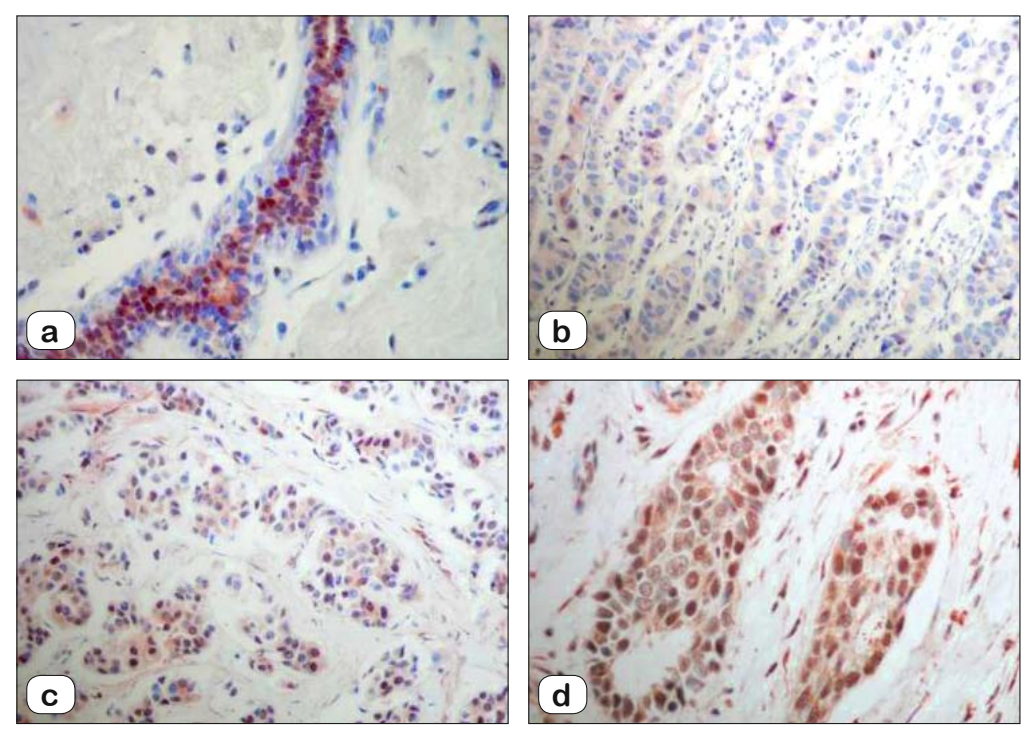

Fig. 2. STAT2 stained glandular epithelium in non-tumor tissue, but no myoepithelial staining (a). G1 (b), G2 (c), G3 (d) STAT2 expression is nuclear but occasionally accompanied by pale cytoplasmic staining.

histological grade of tumor, tumor size, limit of tumor growth, presence of desmoplasia, necrosis concomitant inflammation, and lymph node metastasis, as well as ER, PR and cerbB2 status of tumor.

\section{Statistical analysis}

The results were statistically analyzed in IBM SPSS for Windows Version 22.0 package program. Numerical variables were summarized with mean \pm standard deviation, and qualitative variables with numbers and percentages. The Kappa coefficient was 
$51-61$

Tab. 3. STAT 3 immmunohistochemical expression and histopathological parameters.

\begin{tabular}{|c|c|c|c|c|c|}
\hline \multirow{2}{*}{ Parameters } & & \multicolumn{4}{|c|}{ Immunohistochemical expression of STAT 3 antibody. } \\
\hline & & Negative & Positive & Correlation & $\mathrm{p}$ \\
\hline \multirow[t]{2}{*}{ Age } & $<40$ & 2 & 2 & \multirow{2}{*}{-0.026} & \multirow{2}{*}{0.855} \\
\hline & $>40$ & 9 & 11 & & \\
\hline \multirow[t]{3}{*}{ Histological grade } & Grade I & $3 / 7(42.9 \%)$ & $4 / 7(57.1 \%)$ & \multirow{3}{*}{0.010} & \multirow{3}{*}{0.522} \\
\hline & Grade II & $5 / 8(62.5 \%)$ & $3 / 8(37.5 \%)$ & & \\
\hline & Grade III & $3 / 9(33.3 \%)$ & $6 / 9(66.7 \%)$ & & \\
\hline \multirow[t]{3}{*}{ Tumor diameter } & $<2$ & $4 / 9(44.4 \%)$ & $5 / 9(55.6 \%)$ & \multirow{3}{*}{0.007} & \multirow{3}{*}{1.000} \\
\hline & $2-5$ & $5 / 11(45.5 \%)$ & $6 / 11(54.5 \%)$ & & \\
\hline & $>5$ & $2 / 4(50 \%)$ & $2 / 4(50 \%)$ & & \\
\hline \multirow[t]{2}{*}{ necrosis } & Present & $8 / 17(37.1 \%)$ & $9(52.9 \%)$ & \multirow{2}{*}{-0.036} & \multirow{2}{*}{1.000} \\
\hline & absent & $4 / 7(32.9 \%)$ & $4(57.1 \%)$ & & \\
\hline \multirow[t]{2}{*}{ Inflammation } & Present & $9 / 21(42.9 \%)$ & $12 / 21(57.1 \%)$ & \multirow{2}{*}{0.111} & \multirow{2}{*}{0.576} \\
\hline & absent & $2 / 3(66.7 \%)$ & $1 / 3(33.3 \%)$ & & \\
\hline \multirow[t]{2}{*}{ Tumor growth pattern at borders } & Infiltratif & $10 / 21(47.6 \%)$ & $11 / 21(52.4 \%)$ & \multirow{2}{*}{0.059} & \multirow{2}{*}{1.000} \\
\hline & expansile & $1 / 3(33.3 \%)$ & $2 / 3(66.7 \%)$ & & \\
\hline \multirow[t]{3}{*}{ cerbB2 status } & Negative & $8 / 17(47.1 \%)$ & $9 / 17(52.9 \%)$ & \multirow{3}{*}{0.145} & \multirow{3}{*}{0.031} \\
\hline & uncertain & - & - & & \\
\hline & positive & $0 / 4$ & $4 / 4(100 \%)$ & & \\
\hline \multirow[t]{2}{*}{ ER status } & Negative & $4 / 7(57.1 \%)$ & $7 / 17(41.2 \%)$ & \multirow{2}{*}{0.137} & \multirow{2}{*}{0.659} \\
\hline & positive & $3 / 7(42.9 \%)$ & $10 / 17(58.8 \%)$ & & \\
\hline \multirow[t]{2}{*}{ PR status } & Negative & $2 / 3(66.7 \%)$ & 9/21 (42.9\%) & \multirow{2}{*}{0.111} & \multirow{2}{*}{0.576} \\
\hline & positive & $1 / 3(33.3 \%)$ & $12 / 21(57.1 \%)$ & & \\
\hline \multirow[t]{3}{*}{ Hormon receptor status } & Positive & $9 / 21(42.9 \%)$ & $12 / 21(57.1 \%)$ & \multirow{3}{*}{0.111} & \\
\hline & Negative & $2 / 3(66.7 \%)$ & $1 / 3(33,3$ & & 0.576 \\
\hline & & & $\%)$ & & \\
\hline LN metastasis & Present & $3 / 12(25 \%)$ & $9 / 12(75 \%)$ & & \\
\hline & absent & $8 / 12(66.7 \%)$ & $4 / 12(33.3 \%)$ & 0.417 & 0.100 \\
\hline Pathological stage & $\mathrm{Ib}$ & $8 / 11(72.7 \%)$ & $3 / 11(27.3 \%)$ & & \\
\hline & IIa & $1 / 10(10 \%)$ & $9 / 10(90 \%)$ & 0.483 & 0.007 \\
\hline & $\mathrm{IIb}$ & $2 / 3(66.7 \%)$ & $1 / 3(33.3 \%)$ & & \\
\hline
\end{tabular}
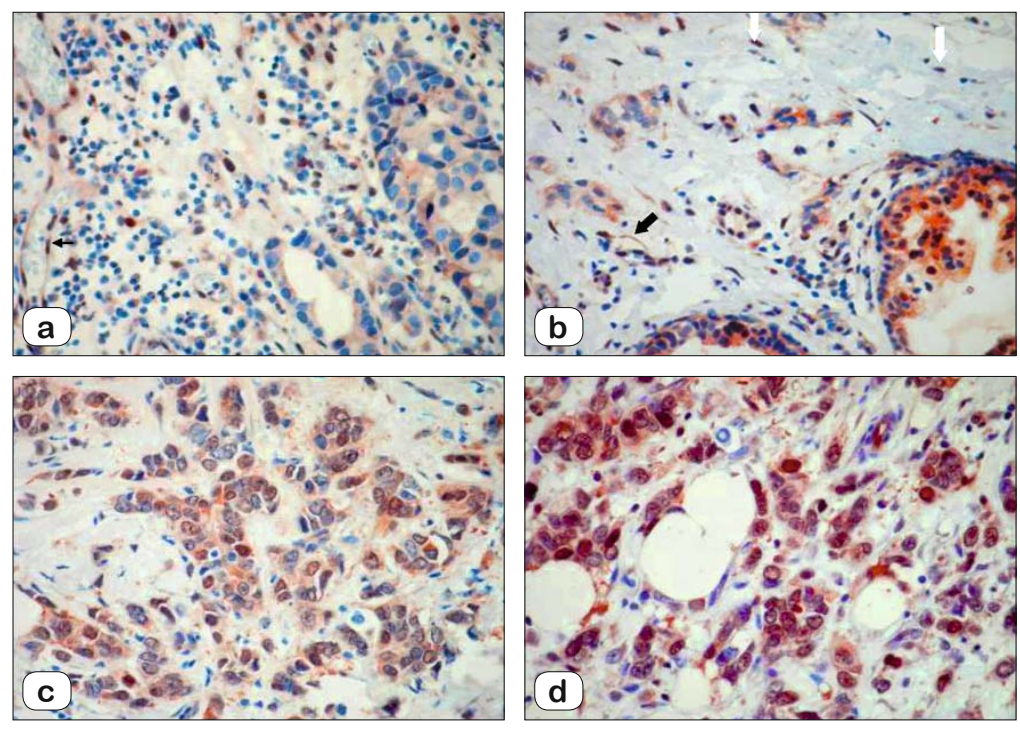

Fig. 3. G0 STAT 3 expression was detected in 11 of the tumor cases (a), G1 STAT 3 expression was detected in 2 of the tumor cases (b), G2 STAT 3 expression was detected in 7 of the tumor cases (c) G3 STAT 3 expression was detected in 4 of tumor cases (d). STAT3 positivity was detected in vascular endothelium (thin arrow) and fibroblasts (thick arrow) in stroma.

employed to present the concordance between staining results and other factors. Kappa coefficient $<0.40$ was accepted to indicate weak concordance, between 0.41 and 0.60 moderate concordance, between 0.61 and 0.80 good concordance, and $>$ 0.80 perfect concordance. Chi-square or Fisher's exact test was utilized to check if there was any difference between the staining groups in terms of other factors. Mann-Whitney U test was used to determine if there was any difference in age between the staining groups. $\mathrm{p}<0.05$ was set as the significance level.

\section{Results}

The age of the 24 patients included in the study was in range of 29-80 years (mean age 58.42). Twenty-three of the cases were female and 1 of them was male. The $\mathrm{M} / \mathrm{F}$ ratio was found to be $1 / 23$. The largest tumor diameter was $9 \mathrm{~cm}$, and the smallest was $1.5 \mathrm{~cm}$ (mean diameter $3.47 \mathrm{~cm}$ ). According to the Modified Bloom-Richardson grading system, 7 of the tumors were of grade I, 8 were of grade II and 9 were of grade III. Out of 12 cases without lymph node metastasis, 3 were of grade I, 4 of grade II, and 5 of grade III. Out of 12 cases with lymph node metastasis, 4 were of grade I, 4 of grade II, and 4 of grade III. When the cases were divided into subtypes according to their molecular features, the majority of them were 
Tab. 4. STAT 5a immmunohistochemical expression and histopathological parameters.

\begin{tabular}{|c|c|c|c|c|c|}
\hline \multirow{2}{*}{ Parameters } & & \multicolumn{4}{|c|}{ Immunohistochemical expression of STAT 5a antibody. } \\
\hline & & Negative & Positive & Correlation & $\mathrm{p}$ \\
\hline \multirow[t]{2}{*}{ Age } & $<40$ & 1 & 3 & \multirow{2}{*}{0.100} & \multirow{2}{*}{0.459} \\
\hline & $>40$ & 9 & 11 & & \\
\hline \multirow[t]{3}{*}{ Histological grade } & Grade I & $3 / 7(42.9 \%)$ & $4 / 7(57.1 \%)$ & \multirow{3}{*}{-0.004} & \multirow{3}{*}{1.000} \\
\hline & Grade II & $3 / 8(37.5 \%)$ & $5 / 8(62.5 \%)$ & & \\
\hline & Grade III & $4 / 9(44.4 \%)$ & $5 / 9(55.6 \%)$ & & \\
\hline \multirow[t]{3}{*}{ Tumor diameter } & $<2$ & $4 / 9(44.4 \%)$ & $5 / 9(55.6 \%)$ & \multirow{3}{*}{-0.013} & \multirow{3}{*}{1.000} \\
\hline & $2-5$ & $4 / 11(36.4 \%)$ & $7 / 11(63.6 \%)$ & & \\
\hline & $>5$ & $2 / 4(50 \%)$ & $2 / 4(50 \%)$ & & \\
\hline \multirow[t]{2}{*}{ necrosis } & Present & $5 / 17(29.4 \%)$ & $12 / 17(70.6 \%)$ & \multirow{2}{*}{0.373} & \multirow{2}{*}{0.085} \\
\hline & absent & $5 / 7(71.4 \%)$ & $2 / 7(28.6 \%)$ & & \\
\hline \multirow[t]{2}{*}{ Inflammation } & Present & $8 / 21(38.1 \%)$ & $13 / 21(61.9 \%)$ & \multirow{2}{*}{0.143} & \multirow{2}{*}{0.550} \\
\hline & absent & $2 / 3(66.7 \%)$ & $1 / 3(33.3 \%)$ & & \\
\hline \multirow[t]{2}{*}{ Tumor growth pattern at borders } & Infiltratif & 9/21 (36.9\%) & $12 / 21(57.1 \%)$ & \multirow{2}{*}{0.037} & \multirow{2}{*}{1.000} \\
\hline & expansile & $1 / 3(33.3 \%)$ & $2 / 3(66.7 \%)$ & & \\
\hline \multirow[t]{3}{*}{ cerbB2 status } & Negative & $7 / 17(41.2 \%)$ & $10 / 17(58.8 \%)$ & \multirow{3}{*}{0.040} & \multirow{3}{*}{0.673} \\
\hline & uncertain & $2 / 3(66.7 \%)$ & $1 / 3(33.3 \%)$ & & \\
\hline & positive & $1 / 4(25 \%)$ & $3 / 4(75 \%)$ & & \\
\hline \multirow[t]{2}{*}{ ER status } & Negative & $0 / 7$ & $10 / 17(58.8 \%)$ & \multirow{2}{*}{-0.522} & \multirow{2}{*}{0.019} \\
\hline & positive & 7/7 (100\%) & 7/17 (41.2\%) & & \\
\hline \multirow[t]{2}{*}{ PR status } & Negative & $0 / 3$ & $10 / 21(47.6 \%)$ & \multirow{2}{*}{-0.238} & \multirow{2}{*}{0.239} \\
\hline & positive & $3(100 \%)$ & $11 / 21(52.4 \%)$ & & \\
\hline \multirow[t]{2}{*}{ Hormon receptor status } & Positive & $10 / 21(47.6 \%)$ & $11 / 21(52.4 \%)$ & \multirow{2}{*}{-0.238} & 0.239 \\
\hline & Negative & $0 / 3$ & $3 / 3(100 \%)$ & & 0.239 \\
\hline LN metastasis & Present & $6 / 12(50 \%)$ & $6 / 12(50 \%)$ & & \\
\hline & absent & $4 / 12(33.3 \%)$ & $8 / 12(66.7 \%)$ & -0.167 & 0.680 \\
\hline Pathological stage & $\mathrm{Ib}$ & $4 / 11(36.4 \%)$ & $7 / 11(63.6 \%)$ & & \\
\hline & IIa & $4 / 10(40 \%)$ & $6 / 10(60 \%)$ & -0.031 & 0.724 \\
\hline & $\mathrm{IIb}$ & $2 / 3(66.7 \%)$ & $1 / 3(33.3 \%)$ & & \\
\hline
\end{tabular}

found to be of luminal type of breast cancer $(\mathrm{n}=$ $21,87.5 \%$ ). In immunohistochemical staining performed with STAT1, $16.6 \%(\mathrm{n}=4)$ of the cases with tumors were negative, while in $16.6 \%(\mathrm{n}=$ 4), $45.8 \%(n=11)$, and $20.8 \%(n=5)$, staining grades 1, 2 and 3 were observed, respectively (Fig. 1). STAT1 expression was not observed in nontumoral epithelial and myoepithelial cells. There was no statistically significant correlation between STAT1 antibody expression in tumor cells and the histological grade, diameter and growth limits of the tumor, presence of intratumoral desmoplasia, presence of inflammation, presence of necrosis, axillary lymph node involvement, estrogen, progesterone, and cerb-B2 staining status $(\mathrm{p}>0.05)$ (Tab. 1). When STAT2 expression was examined, $8.33 \%(\mathrm{n}=2)$ of the cases were negative, while in $20.8 \%(\mathrm{n}=5), 37.5 \%(\mathrm{n}=9)$ and $33.3 \%(\mathrm{n}$ $=8$ ), staining grades 1,2 and 3 were observed, respectively (Fig. 2). No significant results could be found between the STAT2 antibody expression in tumor cells and analyzed histological param-
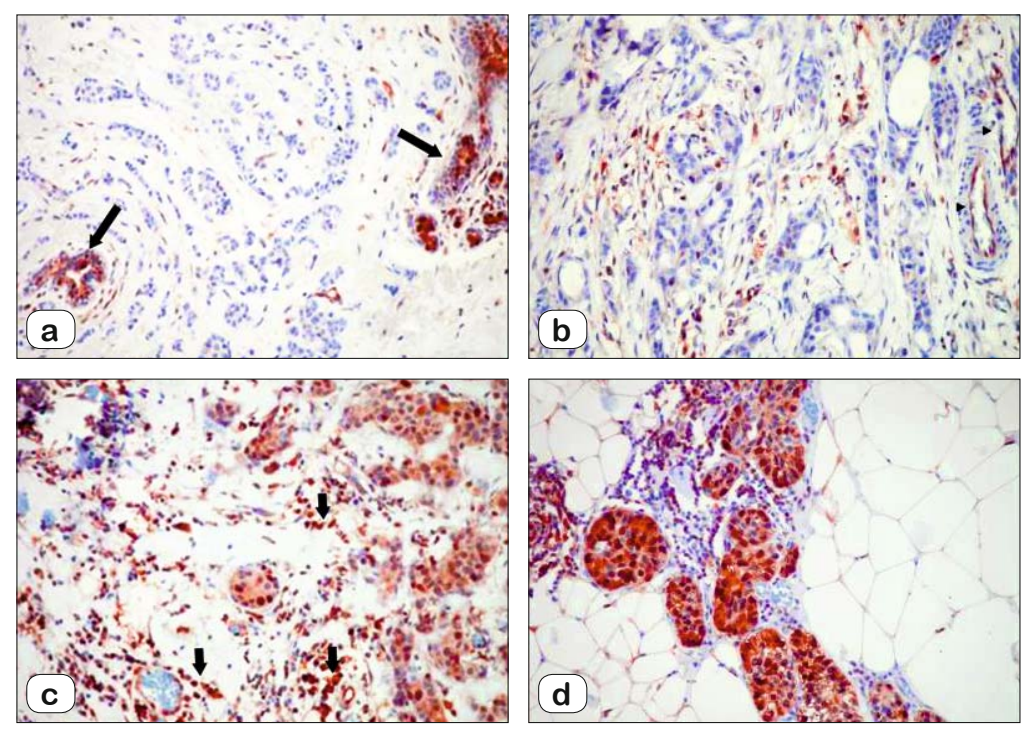

Fig. 4. Nontumoral breast duct epithelium showed strong staining with STAT5a, no staining was seen in myoepithelial cells (long arrow); tumor cells in this Fig. are STAT5anegative (a). Expression of STAT5a was also seen in the vessel endothelium adjacent to the tumor site showing G1 staining (arrow head) (b). In the case evaluated as G2, lymphocytes STAT5a expression was common in the tumor (c). G3, STAT5a expression. eters (Tab. 2).

Immunohistochemical staining with STAT3 revealed staining of the vascular endothelium, nontumoral duct epithelia, lymphocytes, vascular smooth muscle and fibroblasts as well as nuclear

staining in the tumor epithelium. In our study, we identified positive staining with STAT3 in $54.1 \%$ of our cases. While $45.8 \%$ $(\mathrm{n}=11)$ of the cases with tumors were negative; $8.33 \%(\mathrm{n}=2)$, 
$51-61$

Tab 5. HIF-1 $\alpha$ immmunohistochemical expression and histopathological parameters.

\begin{tabular}{|c|c|c|c|c|c|}
\hline \multirow{2}{*}{ Parameters } & & \multicolumn{4}{|c|}{ Immunohistochemical expression of Hif1 $\alpha$ antibody. } \\
\hline & & Negative & Positive & Correlation & $\mathrm{p}$ \\
\hline Age & $\begin{array}{l}<40 \\
>40\end{array}$ & $\begin{array}{l}2 \\
18\end{array}$ & $\begin{array}{l}2 \\
2\end{array}$ & 0.39 & 0.05 \\
\hline Histological grade & $\begin{array}{l}\text { Grade I } \\
\text { Grade II } \\
\text { Grade III } \\
\end{array}$ & $\begin{array}{l}5 / 7(71.4 \%) \\
7 / 8(87.5 \%) \\
8 / 9(98.9 \%) \\
\end{array}$ & $\begin{array}{l}2 / 7(28.6 \%) \\
1 / 8(12.5 \%) \\
1 / 9(11.1 \%) \\
\end{array}$ & 0.036 & 0.644 \\
\hline Tumor diameter & $\begin{array}{l}<2 \\
2-5 \\
>5 \\
\end{array}$ & $\begin{array}{l}8 / 9(88.9 \%) \\
9 / 11(81.8 \%) \\
3 / 4(75 \%) \\
\end{array}$ & $\begin{array}{l}1 / 9(11.1 \%) \\
2 / 11(18.2 \%) \\
1 / 4(25 \%)\end{array}$ & -0.022 & 0.394 \\
\hline necrosis & $\begin{array}{l}\text { Present } \\
\text { absent }\end{array}$ & $\begin{array}{l}14 / 17(82.4 \%) \\
6 / 7(85.7 \%) \\
\end{array}$ & $\begin{array}{l}3 / 17(17.6 \%) \\
1 / 7(14.3 \%) \\
\end{array}$ & 0.022 & 1.000 \\
\hline Inflammation & $\begin{array}{l}\text { Present } \\
\text { absent }\end{array}$ & $\begin{array}{l}18 / 21(95.7 \%) \\
2 / 3(66.7 \%)\end{array}$ & $\begin{array}{l}3 / 21(14.3 \%) \\
1 / 3(33.3 \%)\end{array}$ & -0.056 & 0.437 \\
\hline Tumor growth pattern at borders & $\begin{array}{l}\text { Infiltratif } \\
\text { expansile }\end{array}$ & $17 / 21(81 \%)$ & $\begin{array}{l}\text { 4/21 (19\%) } \\
-\end{array}$ & -0.167 & 1.000 \\
\hline cerbB2 status & $\begin{array}{l}\text { Negative } \\
\text { uncertain } \\
\text { positive }\end{array}$ & $\begin{array}{l}14 / 17(82.4 \%) \\
3 / 4(75 \%)\end{array}$ & $\begin{array}{l}3 / 17(17.6 \%) \\
- \\
1 / 4(25 \%)\end{array}$ & 0.018 & 1.000 \\
\hline ER status & $\begin{array}{l}\text { Negative } \\
\text { positive }\end{array}$ & - & $\begin{array}{l}13 / 17(76.5 \%) \\
4 / 17(23.5 \%) \\
\end{array}$ & 0.152 & 0.283 \\
\hline PR status & $\begin{array}{l}\text { Negative } \\
\text { positive }\end{array}$ & - & $\begin{array}{l}17 / 21(81 \%) \\
4 / 21(19 \%) \\
\end{array}$ & 0.056 & 1.000 \\
\hline Hormone receptor status & $\begin{array}{l}\text { Positive } \\
\text { Negative }\end{array}$ & $17 / 21(81 \%)$ & $\begin{array}{l}4 / 21(19 \%) \\
-\end{array}$ & 0.056 & 1.000 \\
\hline LN metastasis & $\begin{array}{l}\text { Present } \\
\text { absent }\end{array}$ & $\begin{array}{l}8 / 12(66.7 \%) \\
-\end{array}$ & $\begin{array}{l}4 / 12(33.3 \%) \\
-\end{array}$ & 0.333 & 0.093 \\
\hline Pathological stage & $\begin{array}{l}\mathrm{Ib} \\
\mathrm{IIa} \\
\mathrm{IIb} \\
\end{array}$ & $\begin{array}{l}11 / 11(100 \%) \\
7 / 10(70 \%) \\
2 / 3(66,7 \%) \\
\end{array}$ & $\begin{array}{l}- \\
3 / 10(30 \%) \\
1 / 3(33.3 \%) \\
\end{array}$ & 0.241 & 0.146 \\
\hline
\end{tabular}
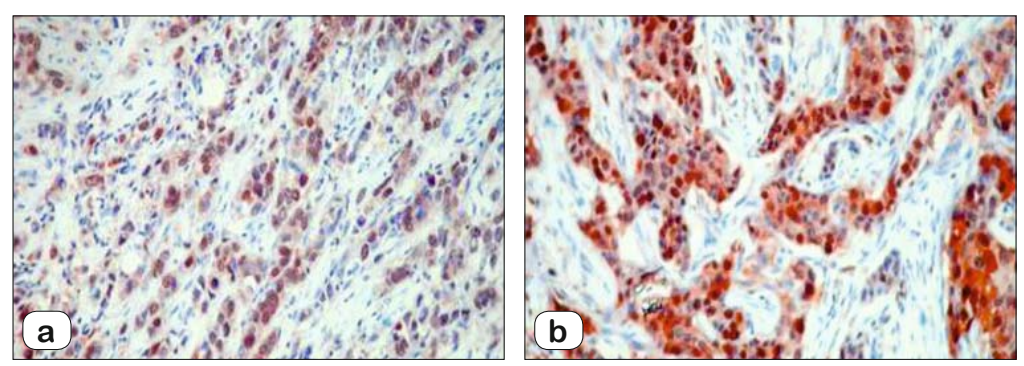

Fig. 5. 23/24 of tumor cases in G3 (a) and 1/24 showed G2 (b) STAT5b expression.
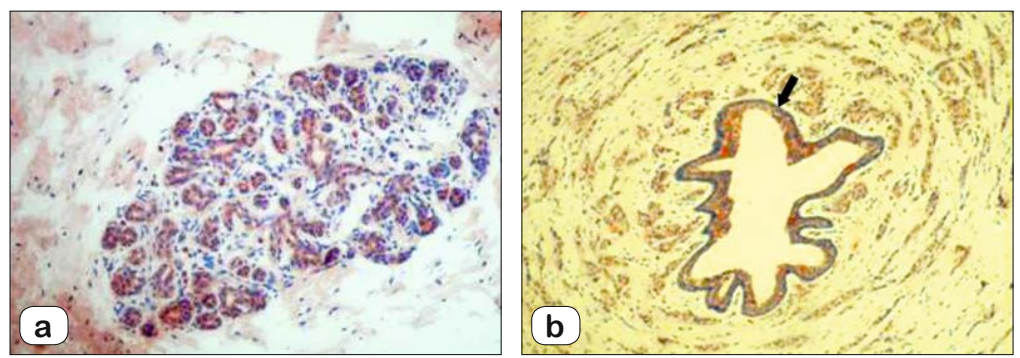

Fig. 6. HIF-1 alpha was stained in the epithelial, intraductal and infiltrative atypical epithelium in non-tumor breast tissue. No staining of lymphocytes in the non-tumor area /No tumor epithelium staining was detected with HIF 1 alpha (grade 0). expression of tumor was found ( $\mathrm{p}$ values 0.007 and 0.031 , respectively) (Tab. 3).

When only the cases with the luminal type of breast carcinomas were evaluated statistically, it was seen that the concordance of STAT3 expression with the pathological stage became more prominent (p 0.004). Similarly, there was a significant relationship between the expressions of cerbB2 and STAT3 only when luminal types were evaluated $(p=0.043)$. However, no correlation was found between other histopathological parameters and STAT3 expression (Tab. 3). When STAT5a staining of cases with tumor was evaluated, $41.6 \%(n=10)$ of them were found to be negative, while $29.1 \%(\mathrm{n}=7), 16.6 \%$ ( $=4)$ and $12.5 \%(n=3)$ exhibited grades 1,2 , and 3 of staining, respectively. While nontumoral breast ductus epithelium exhibited strong staining with STAT5a, myoepithelial cells were not stained. Diffuse STAT5a positivity was observed in vascular endothelium and lymphocytes (Fig. 4). The expressions of STAT 5a and estrogen receptor status of the tumor were found to be sta$29.2 \%(\mathrm{n}=7)$ and $16.6 \%(\mathrm{n}=4)$ exhibited grades $1 ; 2$ and 3 of nuclear staining (Fig. 3). A statistically significant relationship of STAT3 expression with the pathological stage of tumor and cerbB2 tistically significant $(\mathrm{p}<0.05)$. However, no significant correlation was found between STAT5 staining and other parameters $(\mathrm{p}>0.05)$ (Tab. 4). 
Tab. 6. HIF-2 $\alpha$ immmunohistochemical expression and histopathological parameters.

\begin{tabular}{|c|c|c|c|c|c|}
\hline \multirow{2}{*}{ Parameters } & & \multicolumn{4}{|c|}{ Immunohistochemical expression of Hif2 $\alpha$ antibody. } \\
\hline & & Negative & Positive & Correlation & $\mathrm{p}$ \\
\hline \multirow[t]{2}{*}{ Age } & & 2 & 2 & \multirow{2}{*}{-0.05} & \multirow[b]{2}{*}{0.711} \\
\hline & $>40$ & 8 & 12 & & \\
\hline \multirow[t]{3}{*}{ Histological grade } & Grade I & $3 / 7(42.9 \%)$ & $4 / 7(57.1 \%)$ & \multirow{3}{*}{-0.004} & \multirow{3}{*}{1.000} \\
\hline & Grade II & $3 / 8(37.5 \%)$ & $5 / 8(62.5 \%)$ & & \\
\hline & Grade III & $4 / 9(44.4 \%)$ & $5 / 9(55.6 \%)$ & & \\
\hline \multirow[t]{3}{*}{ Tumor diameter } & $<2$ & $5 / 9(55.6 \%)$ & $4 / 9(44.4 \%)$ & \multirow{3}{*}{-0.067} & \multirow{3}{*}{0.635} \\
\hline & $2-5$ & $4 / 11(36.4 \%)$ & $7 / 11(63.6 \%)$ & & \\
\hline & $>5$ & $1 / 4(25 \%)$ & $3 / 4(75 \%)$ & & \\
\hline \multirow[t]{2}{*}{ necrosis } & Present & $5 / 17(47.1 \%)$ & $9 / 17(52.9 \%)$ & \multirow{2}{*}{-0.164} & \multirow{2}{*}{0.653} \\
\hline & absent & $2 / 7(28.6 \%)$ & $5 / 7(71.4 \%)$ & & \\
\hline \multirow[t]{2}{*}{ Inflammation } & Present & 9/21 (42.9\%) & $12 / 21(57.1 \%)$ & \multirow{2}{*}{-0.048} & \multirow{2}{*}{1.000} \\
\hline & absent & $1 / 3(33.3 \%)$ & $2 / 3(66.7 \%)$ & & \\
\hline \multirow[t]{2}{*}{ Tumor growth pattern at borders } & Infiltratif & $8 / 21(38.1 \%)$ & $13 / 21(61.9 \%)$ & \multirow{2}{*}{-0.111} & \multirow{2}{*}{0.550} \\
\hline & expansile & $2 / 3(66.7 \%)$ & $1 / 3(33.3 \%)$ & & \\
\hline \multirow[t]{3}{*}{ cerbB2 status } & Negative & $8 / 17(47.1 \%)$ & $9 / 17(52.9 \%)$ & \multirow{3}{*}{0.040} & \multirow{3}{*}{0.364} \\
\hline & uncertain & $0 / 3$ & $3 / 3(100 \%)$ & & \\
\hline & positive & $2 / 4(50 \%)$ & $2 / 4(50 \%)$ & & \\
\hline \multirow{2}{*}{ ER status } & Negative & $2 / 7(28.6 \%)$ & $8 / 17(47.1 \%)$ & \multirow{2}{*}{-0.164} & \multirow{2}{*}{0.653} \\
\hline & positive & $5 / 7(71.4 \%)$ & $9 / 17(52.9 \%)$ & & \\
\hline \multirow[t]{2}{*}{ PR status } & Negative & $0 / 3$ & $10 / 21(47.6 \%)$ & & \\
\hline & positive & $3 / 3(100 \%)$ & $11 / 21(52.4 \%)$ & -0.238 & 0.239 \\
\hline Hormone receptor status & Positive & $10 / 21(47.6 \%)$ & $11 / 21(52.4 \%)$ & -0238 & 0239 \\
\hline & Negative & $0 / 3$ & $3 / 3(100 \%)$ & -0.238 & 0.239 \\
\hline LN metastasis & Present & $7 / 12(58.3 \%)$ & $5 / 12(41.7 \%)$ & & \\
\hline & absent & $3 / 12(25 \%)$ & $9 / 12(75 \%)$ & -0.333 & 0.214 \\
\hline Pathological stage & $\mathrm{Ib}$ & $3 / 11(27.3 \%)$ & $8 / 11(72.7 \%)$ & & \\
\hline & IIa & $6 / 10(60 \%)$ & $4 / 10(40 \%)$ & -0.252 & 0.326 \\
\hline & $\mathrm{IIb}$ & $1 / 3(33.3 \%)$ & $2 / 3(66.7 \%)$ & & \\
\hline
\end{tabular}

Nuclear and cytoplasmic staining was detected in tumor cells with STAT5b. All of the cases with tumor were stained with STAT5b, while in $4.16 \%$ of cases $(n=1)$, and $95.83 \%$ of cases ( $n$ $=23$ ), grades 2 , and 3 of staining were observed, respectively (Fig. 5). Due to the fact that STAT 5b was expressed in all cases, no statistical analysis could be conducted. No correlation was found between the parameters related to the degree of staining $(p>0.05)$. In our study, the staining with STAT 2, STAT3, and STAT5a was positive also in nontumoral breast ductus epithelium. While $84 \%$ $(\mathrm{n}=20)$ of the cases were negative after staining with HIF $1 \alpha ; 8 \%(n=2), 4 \%(n=1)$ and $4 \%(n$ $=1$ ) exhibited grades $1 ; 2$, and and 3 of staining, respectively. While the staining with HIF $1 \alpha$ was present in non-tumorous breast tissue epithelium, intraductal and infiltrative atypical epithelium, and myoepithelial cells were not HIF1 $\alpha$ positive. No lymphocytes were stained in the non-tumor area.
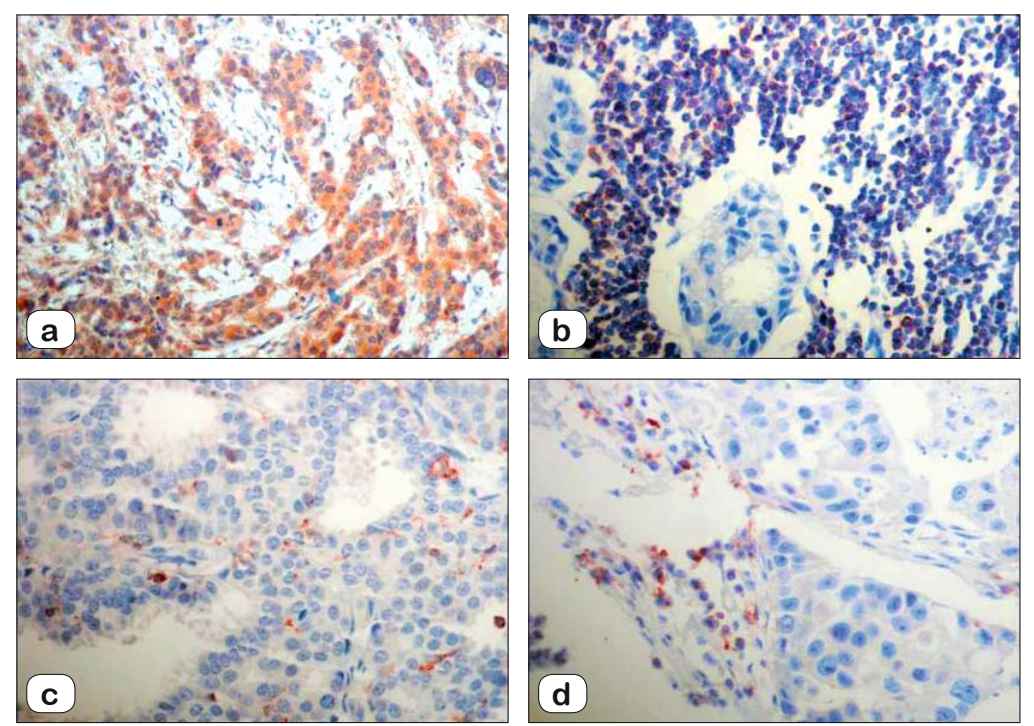

Fig. 7. HIF2 alpha showed nuclear and cytoplasmic staining in epithelial cells, nuclear staining rated (a). HIF2alpha was expressed in lymphocytes within the tumor (b, c, d).
There was also nuclear staining of lymphocytes

in the lymphoid response to the tumor (Fig. 6). No significant correlation of HIF1 $\alpha$ expression in tumors with lymphocytes and evaluated parameters was found ( $p>0.05)$ (Tab. 5).

The staining with HIF2 $\alpha$ resulted in the staining of intratumor lymphocytes as well as tumor cells (Fig. 7). In addition, myoepithelial cells and smooth muscle cells of the vascular wall were also stained. The staining with HIF2 $\alpha$ resulted in $41.66 \%$ of cases $(n=10)$ being negative, while $16.6 \%(n=4)$ and 41.66 $\%(n=10)$ displayed grades 1 and 2 of staining, respectively. In the statistical research, no statistically significant correlation was 
found between pathological parameters and HIF2 $\alpha$ expression $(p>0.05)$ (Tab. 6).

\section{Discussions}

While n our study on patients with invasive ductal carcinoma, the STAT3 expression was concordant with the pathological stage and CerbB2 positivity, no correlation was found between STAT3 expression and other parameters. Besides, there was a significant correlation between STAT5a expression of tumor cells and estrogen receptor positivity whereas no significant correlation was found between STAT5a expression and other parameters. No significant correlation was found between the tumor expression of other immunohistochemical markers of STAT1, STAT2, STAT 5b, HIF $1 \alpha$, HIF $2 \alpha$ and the pathological stage of tumor, nuclear grade of tumor, desmoplasia in tumor, presence of necrosis and inflammation, and ER, PR and CERB-B2 status of tumor. Breast carcinoma is the most common malignant tumor in women, while more than $1,000,000$ women are diagnosed with breast carcinoma annually (1). It is also the most common cause of death from carcinomas in women. Although breast cancer is seen in any age group, it rarely occurs under 25 years of age. In our study, the age of the patients ranged between 29 and 80 years. Breast cancer is molecularly classified into five main subtypes: luminal A, luminal B, Her2 (+), triplenegative and normal-like (19). In accordance with literature, most of the cases in our study were of the luminal subtypes $(n=21)$.

STAT3, the major element of the STAT family, plays an important role in cell differentiation and proliferation $(9,20)$ In addition, the studies on breast and hematopoietic cells have shown that STAT3 also plays a role as an oncogenic protein and it has been suggested that it may be related also to chemotherapy resistance $(21,22)$. It is stated that STAT3 is especially activated in breast cancer and it contributes to cancer progression by stimulating cell proliferation, increasing angiogenesis, influencing escape from the immune system and providing resistance to apoptosis (23-26). Although it has been shown in the conducted studies that STAT3 is expressed to a certain extent in all breast cancer subtypes, the information on its prognostic significance is contradictory (27). While in some publication it was reported that nuclear STAT3 expression was associated with better survival, in some others no correlation was found with the prognosis or ER expression $(28,29)$. In a recent study, activated STAT3 has been reported to be an indicator of good prognosis in luminal breast cancers (30). In our study, STAT3 expression was concordant with the pathological stage, and it was found to have significantly higher correlation with luminal breast cancer $(p=0.004)$. Moreover, in concordance with the results found by Diaz et al. (31), in our study, a statistically significant relationship was found between cerbB2 positivity and STAT3 expression $(p=0.041)$. However, there was no significant relationship between STAT3 expression and other parameters included in our study. STAT5a, another important member of the STAT family, is required for the growth, proliferation and differentiation of cells in the breast epithelium (32-35). In accordance with literature, in our study, it was observed that STAT5a was also stained in nontumoral breast tissue, lymphocytes and fibroblasts (36). In a study, it was stated that there was a decrease in STAT5a activation in metastatic tumors, and it was an independent factor for good prognosis in human breast cancer (37). STAT5a protein expression was shown not to be statistically significant although it differed slightly. In our study, we observed that the loss in STAT5a expression was higher in lymph node positive cases, but no statistically significant result was obtained. In another study evaluating the STAT5a protein expression in breast cancer, a significant correlation was found between nuclear staining of STAT5a and increased histological grade (38). In our study, we observed diffuse STAT5a expression in the nontumoral duct epithelium in parallel with breast development. Although the ratios were different, the comparison of STAT5a expression in normal and hyperplastic epithelium and in carcinoma cells revealed a significant loss in STAT5a expression also in our study. However, we could not detect any correlation between the histological grade and STAT5a expression. In addition, STAT5a and estrogen staining $(p<0.05)$, which is a good prognostic factor, were found to be statistically significant also in our study. STAT5a and STAT5b are involved in the development of breast cells in conjunction with PR and are regulated by the PR-mediated pathway in conjunction with STAT3 in breast cancer. However, in our study, neither STAT3 nor STAT5a/b was associated with PR expression (39). In our study, no significant result was found between STAT3 and ER and PR, but a significant result was found between STAT5a and ER. STAT5b, present in normal breast epithelial cells, is an isoform of STAT5a, resulting from gene duplication (40). STAT5b was examined Immunohistochemically only in one published study, in which however, the results of staining have not been reported (41). In our study, we found strong nuclear staining in all of our cases and therefore, we could not analyze its correlation with prognostic parameters. Nevertheless, the staining of all ductal carcinomas suggests it might have a role in tumor development. In many published studies, no correlation could be shown between STAT1 expression in breast carcinomas and age, estrogen receptor status, histological grade, primary tumor stage, lymph node status and tumor-node-metastasis (TNM) stage (40). In a study conducted although on a very large series, STAT1 staining was observed in $27 \%$ of ER-positive tumors and was reported to be associated with shorter disease-free survival (42). In our study, we observed staining in $83.3 \%$ of the cases and, in accordance with the majority of published studies, we could not obtain a statistically significant result between STAT1 expression and tumor parameters. STAT2 expression in human breast carcinomas is not well defined in literature. Only a few studies on cell lines have reported its expression in breast cancer cells (43). In our study, $91.6 \%$ of the cases were found to display nuclear staining with STAT2. Both STAT1 and STAT2 are necessary factors for interferon response and signaling. As a result of STAT1 gene deletion, the interferon response is eliminated $(41,44)$. STAT2 is required for IFN- $\gamma$ signaling, and together with STAT1, it is involved in interferon response. Considering the fact that interferons are still used in the treatment of some breast cancers, we think that further studies with STAT1 and STAT2 will be useful. 
The adaptation to the hypoxic environment for the survival and development of tumor cells is mainly determined by the HIF (hypoxia inducing factor)-dependent transcription program. HIF $1 \alpha$ and HIF $2 \alpha$ are important proteins that initiate tumor cell responses to hypoxia (45). HIFs mainly increase the angiogenesis, and cause the progression of the tumor in an aggressive course $(46,48)$. The literature has revealed a significant association between low surveillance and high HIF $1 \alpha$ levels in patients with bladder, breast, endometrial, cervical, oropharyngeal and esophageal carcinomas $(45,48-61)$. In addition, HIF $1 \alpha$ has been reported to be associated with poor prognosis in pancreatic tumors (62). In various studies on breast carcinomas, high HIF $1 \alpha$ levels have been reported to be associated with a shorter life span $(45,60,63)$. Also in our study, there was no HIF $1 \alpha$ expression observed in cases without lymph node metastasis. In addition, we found that all of the cases stained positive for HIF $1 \alpha$ had lymph node metastasis with infiltrative tumor boundaries. Nevertheless, our findings were not statistically significant. Despite the lack of a thorough comparison of life span, our results are consistent with findings in literature, and the presence of correlation between HIF $1 \alpha$ expression and lymph node positivity, an important parameter in determining tumor stage, supports the negative correlation between patient prognosis and HIF $1 \alpha$. Besides, its correlation with infiltrative tumor boundary may be associated with the development and spread potential of the tumor. The increase in HIF $1 \alpha$ is associated with breast carcinogenesis and has been reported in the literature to exist especially in cases with low differentiation (64). In our study, however, there was no significant correlation between HIF1 $\alpha$ expression and tumor differentiation. Hypoxia has been reported to trigger cell differentiation and cancer progression with the downregulation of ER expression. It is suggested in literature that ER increases the hypoxic response caused by HIF and thus leads to a more malignant phenotype $(45,65)$. In our study, all cases stained with HIF1 $\alpha$ were identified to be ER positive but no statistically significant result was obtained. In a previous study on HIF $2 \alpha$, the HIF $2 \alpha$ expression was detected in $36 \%$ of ductal carcinomas of the breast. In our study though, we found HIF $2 \alpha$ expression in $58 \%$ of our cases. While in the aforementioned study, there was no correlation between hormone receptors, Cerb-B2 and HIF2 $\alpha$ expression, there was a significant correlation with the presence of lymph node metastasis. In our study, on the other hand, there was an increased expression of HIF2 $\alpha$ in PR receptor positive cases, and no statistically significant correlation was observed between PR and HIF2 $\alpha$. No significant correlation was found with the presence of lymph node metastasis, which may be due to the low number of cases with lymph node metastasis in our study. In literature, no significant correlation consistent with present findings was found between HIF2 $\alpha$ and Cerb-B2 expression and other prognostic parameters.

\section{Conclusion}

Consequently, our study reveals that among the immunohistochemical markers examined, only STAT3 expression correlates with an advanced pathological stage, and has a prognostic value.

\section{References}

1. Bray F, Ferlay J, Soerjomataram I, Siegel RL, Torre LA, Jemal A. Global cancer statistics 2018: GLOBOCAN estimates of incidence and mortality worldwide for 36 cancers in 185 countries. CA Cancer J Clin 2018; 68 (6): 394-424. doi: 10.3322/caac.21492.

2. Wang R, Zhou S, Li S. Cancer therapeutic agents targeting hypoxiainducible factor-1. Curr Med Chem 2011; 18 (21): 3168-3189.

3. Li Y, Ye D. Cancer therapy by targeting hypoxia-inducible factor-1. Curr Cancer Drug Targets 2010; 10 (7): 782-796.

4. Maxwell PH. The HIF pathway in cancer. Semin Cell Dev Biol 2005; 16 (4-5): 523-530.

5. Xu R. P4HA1 is a new regulator of the HIF-1 pathway in breast cancer. Cell Stress 2019; 3 (1): 27-28.

6. Freeburg PB, Robert B, St John PL, Abrahamson DR. Podocyte ekspression of Hypoxia-inducible factor (HIF)-1 and HIF-2 during glomerular development. J Am Soc Nephrol 2003; 14 (4): 927-938.

7. Semenza GL. Hypoxia-inducible factors: mediators of cancer progression and targets for cancer therapy. Trends Pharmacol Sci 2012; 33 (4): 207-214.

8. Haricharan S, Li Y. STAT signaling in mammary gland differentiation, cell survival and tumorigenesis. Mol Cell Endocrinol 2014;382 (1): 560-569.

9. Clevenger CV. Roles and regulation of stat family transcription factors in human breast cancer. Am J Pathol 2004; 165 (5): 1449-1460.

10. Darnell JE Jr, Kerr IM, Stark GR. Jak-STAT pathways and transcriptional activation in response to IFNs and other extracellular signaling proteins. Science 1994; 264 (5164): 1415-1421.

11. Porritt RA, Hertzog PJ. Dynamic control of type I IFN signalling by an integrated network of negative regulators. Trends Immunol 2015; 36 (3): $150-160$.

12. Zhong Z, Wen Z, Darnell JE Jr. Stat3: a STAT family member activated by tyrosine phosphorylation in response to epidermal growth factor and interleukin-6. Science 1994; 264 (5155): 95-98.

13. Kaplan MH, Sun YL, Hoey T, Grusby MJ. Impaired IL-12 responses and development of Th2 cells in Stat 4 deficient mice. Nature 1996; 382: 174-177.

14. Bowman T, Garcia R, Turkson J, Jove R. STATs in oncogenesis, Oncogene 2000; (19): 2474-2488.

15. Loh CY, Arya A, Naema AF, Wong WF, Sethi G, Looi CY. Signal Transducer and Activator of Transcription (STATs) Proteins in Cancer and Inflammation: Functions and Therapeutic Implication. Front Oncol 2019; 9: 48 .

16. Laudisi F, Cherubini F, Monteleone G, Stolfi C. STAT3 Interactors as Potential Therapeutic Targets for Cancer Treatment. Int J Mol Sci 2018; 19 (6): pii: E1787. doi: 10.3390/ijms19061787.

17. Wang S, Yu L, Shi W, Li X, Yu L. Prognostic roles of signal transducers and activators of transcription family in human breast cancer. Biosci Rep 2018; 38 (6): pii: BSR20171175.

18. Watson CJ, Miller WR. Elevated levels of members of the STAT family of transcription factors in breast carcinoma nuclear extracts. Br J Cancer 1995; 71 (4): 840-844.

19. Russnes HG, Lingjærde OC, Borresen-Dale AL, Caldas C. Breast Cancer Molecular Stratification: From Intrinsic Subtypes to Integrative Clusters. Am J Pathol 2017; 187 (10): 2152-2162. 
$51-61$

20. Buettner R, Mora LB, Jove R. Activated STAT signaling in human tumors provides novel molecular targets for therapeutic intervention. Clin Cancer Res 2002; 8 (4): 945-954.

21. Real PJ, Sierra A, De Juan A, Segovia JC, Lopez-Vega JM, Fernandez-Luna JL. Resistance to chemotherapy via Stat3-dependent overexpression of Bcl-2 in metastatic breast cancer cells. Oncogene 2002; 21 (50): 7611-7618.

22. Dalton WS, Jove R. Drug resistance in multiple myeloma: approaches to circumvention. Semin Oncol 1999; 26 (5 Suppl 13): 23-27.

23. Wang T, Niu G, Kortylewski M, Burdelya L, Shain K, Zhang S, Bhattacharya R, Gabrilovich D, Heller R, Coppola D, Dalton W, Jove R, Pardoll D, Yu H. Regulation of the innate and adaptive immune responses by Stat-3 signaling in tumor cells. Nat Med 2004; (10): 48-54.

24. Aoki Y, Feldman GM, Tosato G. Inhibition of STAT3 signaling induces apoptosis and decreases survivin expression in primary effusion lymphoma. Blood 2003; 101 (4): 1535-1542.

25. Wei LH, Kuo ML, Chen CA, Chou CH, Lai KB, Lee CN, Hsieh CY. Interleukin-6 promotes cervical tumor growth by VEGF-dependent angiogenesis via a STAT3 pathway. Oncogene 2003; 22 (10): 1517-1527.

26. Niu G, Wright KL, Huang M, Song L, Haura E, Turkson J, Zhang S, Wang T, Sinibaldi D, Coppola D, Heller R, Ellis LM, Karras J, Bromberg J, Pardoll D, Jove R, Yu H. Constitutive Stat3 activity upregulates VEGF expression and tumor angiogenesis. Oncogene 2002; 21 (13): 2000-2008.

27. Furth PA. STAT Signaling in Different Breast Cancer Sub-types. Mol Cell Endocrinol 2014; 382 (1): 10.1016/j.mce.2013.03.023.

28. Dolled-Filhart M, Camp RL, Kowalski DP, Smith BL, Rimm DL. Tissue microarray analysis of signal transducers and activators of transcription 3 (Stat3) and phospho-Stat3 (Tyr705) in node-negative breast cancer shows nuclear localization is associated with a better prognosis. Clin Cancer Res 2003; 9 (2): 594-600.

29. Yeh YT, Ou-Yang F, Chen IF, Yang SF, Wang YY, Chuang HY, Su JH, Hou MF, Yuan SS. STAT3 ser727 phosphorylation and its association with negative estrogen receptor status in breast infiltrating ductal carcinoma. Int J Cancer 2006; 118 (12): 2943-2947.

30. Sonnenblick A, Salgado R, Brohée S, Zahavi T, Peretz T, Van den Eynden G, Rouas G, Salmon A, Francis PA, Di Leo A, Crown JPA, Viale G, Daly L, Javdan B, Fujisawa S, De Azambuja E, Lieveke A, Piccart MJ, Bromberg JF, Sotiriou C. p-STAT3 in luminal breast cancer: Integrated RNA-protein pooled analysis and results from the BIG 2-98 phase III trial. Int J Oncol 2018; 52 (2): 424-432.

31. Diaz N, Minton S, Cox C, Bowman T, Gritsko T, Garcia R, Eweis I, Wloch M, Livingston S, Seijo E, Cantor A, Lee JH, Beam CA, Sullivan D, Jove R, Muro-Cacho CA. Activation of stat3 in primary tumors from high-risk breast cancer patients is associated with elevated levels of activated SRC and survivin expression. Clin Cancer Res 2006; 12 (1): 20-28.

32. Liu X, Robinson GW, Wagner KU et al. Stat5a is mandatory for adult mammary gland development and lactogenesis. Genes Dev 1997; 11: 179-186.

33. Miyoshi K, Shillingford JM, Smith GH et al. Signal transducer and activator of transcription (stat) 5 controls the proliferation and differation of mammary alveoler epithelium. J. Cell Biol 2001; 155: 531-542.

34. Bratthauer GL, Strauss BL, Tavassoli FA. STAT5a expression in various lesions of the breast 2006; 448: 165-171.
35. Leehy KA, Truong TH, Mauro LJ, Lange CA. Progesterone receptors (PR) mediate STAT actions: PR and prolactin receptor signaling crosstalk in breast cancer models. J Steroid Biochem Mol Biol 2018; 176: 88-93.

36. Nevalainen MT, Xie J, Torhost J, Bubendorf L, Haas P, Kononen J, Sauter G, Hallgeir R. Signal transducer and activator of transcription-5 activation and breast cancer prognosis. J Clin Oncol 2004; 22 (11): 2053-2060.

37. Cotarla I, Ren S et al. Stat5a is tyrosine phosphorylated and nuclear localized in a high proportion of human breast cancers. Int J Cancer 2004; 108 (5): 665-671.

38. Richer JK, Lange CA, Manning NG, Owen G, Powell R, Horwitz KB. Convergence of progesterone with growth factor and cytokine signaling in breast cancer. Progesterone receptors regulate signal transducers and activators of transcription expression and activity. J Biol Chem 1998; 273 (47): 31317-31326.

39. Canbay E, Norman $M$ et al. Prolactin stimulates the JAK2 and focal adhesion kinase pathways in human breast carcinoma T47-D cells. Biochem J 1997; 324 (Pt 1): 231-236.

40. Sheen-Chen SM, Huang CC, Tang RP, Yang CH, Chou FF, Eng HL. Signal transducer and activator of transcription 1 in breast cancer: analysis with tissue microarray 2007; 27 (4B): 2481-2486.

41. Durbin JE, Hackenmiller R, Simon MC, Levy DE. Targeted disruption of the mouse öStat 1 gene results in compromised innate immunity to viral disease. Cell 1996; 84 (3): 443-450.

42. Charpin C, Secq V, Giusiano S, Carpentier S, Andrac L, Lavaut MN, Allasia C, Bonnier P, Garcia S. A signature predictive of disease outcome in breast carcinomas, identified by quantitative immunocytochemical assays. Int J Cancer 2009; 124 (9): 2124-2134.

43. Uluer ET1, Aydemir I, Inan S, Ozbilgin K, Vatansever HS. Effects of 5-fluorouracil and gemcitabine on a breast cancer cell line (MCF-7) via the JAK/STAT pathway. Acta Histochem 2012; 114 (7): 641-646.

44. Meraz MA, White JM, Sheehan KC, Bach EA, Rodig SJ, Dighe AS, Kaplan DH, Riley JK, Greenlund AC, Campbell D, Carver-Moore K, DuBois RN, Clark R, Aguet M, Schreiber RD. Targeted disruption of the Stat 1 gene in mice reveals unexpected physiologic specificity in the JAK-STAT signaling pathway. Cell 1996; 84 (3): 431-442.

45. Giatromanolaki A, Sivridis E, Fiska A, Koukourakis MI. Hypoxia-inducible factor-2 alpha (HIF-2 alpha) induces angiogenesis in breast carcinomas. Appl Immunohistochem Mol Morphol 2006; 14 (1): 78-82.

46. Schindl M, Schoppmann SF, Samonigg $H$ et al. Overexpression of hypoxia-inducible factor- $1 \alpha$ associated with an unfavorible prognosis in lymph node-positive breast cancer. Clin Cancer Res 2002; 8: $1831-1837$

47. He H, Wang X, Chen J, Sun L, Sun H, Xie K. High-Mobility Group Box 1 (HMGB1) Promotes Angiogenesis and Tumor Migration by Regulating Hypoxia-Inducible Factor 1 (HIF-1 $\alpha$ ) Expression via the Phosphatidylinositol 3-Kinase (PI3K)/AKT Signaling Pathway in Breast Cancer Cells. Med Sci Monit 2019; 25: 2352-2360.

48. Theodoropulps VE, Lazaris AC, Sofras F et al. Hypoxia-inducible factor-1 $\alpha$ expression correlates with angiogenesis and unfavorable prognosis in bladder cancer. Eur Urol 2004; 46: 200-208.

49. Sivridis E, Giatromanolaki A, Gatter KC, Harris AL, Koukourakis MI. Tumor and Angiogenesis Research Group. Association of hypoxiainducible factors 1alpha and 2alpha with activated angiogenic pathways and prognosis in patients with endometrial carcinoma. Cancer 2002; 95 (5): 1055-1063. 
50. Burri P, Djonov V, Aebersold DM et al. Significant correlation of hypoxia-inducible factor- $1 \alpha$ with treatment outcome in cervical cancer treated with radical radiotherapy. Int J Rad Oncol Biol Phys 2003; 56 : 494-501.

51. Jacobsson H, Harrison H, Hughes É, Persson E, Rhost S, Fitzpatrick P, Gustafsson A, Andersson D, Gregersson P, Magnusson Y, Ståhlberg A, Landberg G. Hypoxia-induced secretion stimulates breast cancer stem cell regulatory signalling pathways. Mol Oncol 2019.

52. Birner P, Schindl M, Obermair A, Plank C, Breitenecker G, Oberhuber G. Overexpression of hypoxia-inducible factor 1alpha is a marker for an unfavorable prognosis in early-stage invasive cervical cancer. Cancer Res 2000; 60 (17): 4693-4696.

53. Chakraborty C, Mitra S, Roychowdhury A, Samadder S, Dutta S, Roy A, Das P, Mandal RK, Sharp TV, Roychoudhury S, Panda CK. Deregulation of MLIMD1-VHL-HIF-1 $\alpha$-VEGF pathway is associated with different stages of cervical cancer. Biochem J 2018; 475 (10): 1793-1806.

54. Aebersold DM, Burri P, Beer KT et al. Expresion of hypoxia-inducible factor- $1 \alpha$ : a novel predictive and prognostic parameter in the radiotherapy of oropharyngeal cancer. Cancer Res 2001; 61: 2911-2916.

55. Gong L, Zhang W, Zhou J, Lu J, Xiong H, Shi X, Chen J. Prognostic value of HIFs expression in head and neck cancer: a systematic review. PLoS One 2013; 8 (9): e75094.

56. Xie W, Liu L, He H, Yang K. Prognostic value of hypoxia-inducible factor-1 Nalpha in nasopharyngeal carcinoma: a meta-analysis. Int J Biol Markers 2018; 1724600818778756.

57. Hui EP, Chan AT, Pezzella F et al. Coexpression of hypoxia-inducible factor- $1 \alpha$ and $2 \alpha$, carbonic anhydrase IX, and vascular endothelial growth factor in nasopharyngeal carcinoma and relationship to survival. Clin Cancer Res 2002; 8: 2595-2604.
58. Zhao X, Tang YP, Wang CY, Wu JX, Ye F. Prognostic values of STAT3 and HIF-1 $\alpha$ in esophageal squamous cell carcinoma. Eur Rev Med Pharmacol Sci 2019; 23 (8): 3351-3357.

59. Matsuyama T, Nakanishi K, Hayashi T et al. Expression of hypoxiainducible factor-1 $\alpha$ in esophageal squamous cell carcinoma. Cancer Sci 2005; 96: 176-182.

60. Kurokawa T, Miyamoto M, Kato K et al. Overexpression of hypoxia-inducible factor- $1 \alpha(\mathrm{HIF}-1 \alpha)$ in oesophageal squamous cell carcinoma correlates with lymph node metastasis and pathologic stage. Br J Cancer 2003; 89: 1042-1047.

61. Vleugel MM, Greijer AE, Shvarts A et al. Differantial prognostic impact of hypoxia induced and diffuse HIF- $1 \alpha$ expression in invasive breast cancer. J Clin Pathol 2005; 58: 172-177.

62. Miyake K, Yoshizumi T, Imura S, Sugimoto K, Batmunkh E, Kanemura H, Morine Y, Shimada M. Expression of hypoxia-inducible factor1alpha, histone deacetylase 1, and metastasis-associated protein 1 in pancreatic carcinoma: correlation with poor prognosis with possible regulation. Pancreas 2008; 36 (3): e1-9.

63. Bos R, van der Groep P, Greijer AE, Shvarts A, Meijer S, Pinedo HM, Semenza GL, van Diest PJ, van der Wall E. Levels of hypoxiainducible factor-1alpha independently predict prognosis in patients with lymph node negative breast carcinoma. Cancer 2003; 97 (6): 1573-1581.

64. Bos R, Zhong H, Hanrahan CF, Mommers EC, Semenza GL, Pinedo HM, Abeloff MD Simons JW, Van Diest PJ, Van der Wall E: Levels of hypoxia-inducible factor- $1 \alpha$ during brest carcinogenesis. J Natl Cancer Inst 2001, 93: 309-314.

65. Ao A, Wang H, Kamarajugadda S, Lu J. Involvement of estrogenrelated receptors in transcriptional response to hypoxia and growth of solid tumors. Proc Natl Acad Sci USA 2008; 105 (22): 7821-7826.

Received July 8, 2019. Accepted August 14, 2019. 